\title{
When Citizens Are Minority: Toward Establishing A Comprehensive Emirati SME Support System
}

\begin{abstract}
Abbas Abdelkarim
\section{Abstract}

This paper endeavours to contribute to developing a comprehensive framework of institutional support system in a situation where citizens and citizen-owned SMEs form a minority in their own country. This is significant because it is not confined only to the case study of this Paper, (United Arab Emirates), but is prevalent in all countries of Gulf Cooperation Council.

Examining the current situation of Emirati-owned SME reveals many challenges and opportunities. After developing an empirical framework for SME support and providing analysis of the Emirati SME scene, the paper uses the benchmarking approach (and Singapore has been selected for this purpose), and refers to other relevant literature, to discuss and develop constituents of the proposed support system. It concludes that Emirati SME support system may not be sustainable if not linked to a broader strategy for the development of the country's entire SME sector. Such a strategy, which the paper has not extended into, remains to be an area for future research.
\end{abstract}

Keywords: Emirati SMEs; minority entrepreneurs; SME support system; benchmarking approach; UAE economic development; Gulf SMEs.

\section{Introduction, Research Problem and Research Objective}

\section{Introduction and Background to the Research Problem}

The United Arab Emirates (UAE) is one of the six oil producing and exporting countries that constitute the Gulf Cooperation Council (GCC); others are Bahrain, Kuwait, Oman, Saudi Arabia and Qatar. The six countries share many similarities in their economic, social, political, demographic and cultural structures. As a result of colossal incomes derived from exportation of oil and gas, the GCC governments embarked on executing huge modern infrastructural projects and developing vast health and education facilities and other services in the last four decades. The enormous government investments pushed the level of economic activities to new unprecedented heights (see, among others, Beblawi and Lunciani, 1987 and Abdelkarim, 1999).
The huge development projects called for importation of foreign labour, whose influx has been progressing at unparalleled level, and has led to a complete transformation of demographic structures in all countries of the GCC. Expatriates have become majority in population and labour force of the GCC region. While the GCC countries' stock of immigrant workers has been growing, their own local labour force has been facing increasing difficulties in finding jobs. Due to competition with the expatriates, citizens have opted to seek jobs $\mathrm{t}$ in the public sector that is offering priority of (more rewarding) employment to them. 'Concern of the governments is that public sector jobs are not expanding at a rate commensurate with that of an increasingly educated national labour force, and the private sector employment has become the unchallenged domain of foreign workers' (Abdelkarim, 2001/a, p.2). Nationalisation polices and projects aiming at expanding employment opportunities (including 
self-employment) for the citizens are being developed in all GCC countries.

Before signing the union between the emirates in 1971 (Abu Dhabi, Ajman, Dubai, Fujairah, Sharjah and Umm Al-Quwain; Ras Al-Khaimah emirate joined in 1972), their political umbrella was The Trucial States Development Council. The Council organised the first population census in 1968. By then, the local population formed majority. The 1970's witnessed significant transformations: the establishment of the UAE, production and exportation of oil and the start of massive infrastructural and social service projects and wide-ranging economic activities. By 1975, non-citizens became majority in the population and labour force of the country, and ever since their proportion has been augmenting. The citizens formed $20.1 \%$ of the total population in the last census in 2005 , and $11.5 \%$ only according to (the Government's latest) official estimates in 2010. Expatriates dominated the labour force by 90.9\% in the latest census, making the UAE the world's extreme case of dependency on foreign labour (Abdelkarim, 2001/b; Ministry of Planning, 2007; NBS, 2015).

UAE is classified by the World Bank as a highincome country. According to the World Bank Country Data (World Bank, 2015), UAE GDP at current USD in 1980 was estimated at 43.6 billion; in 1990: 50.7; 2000: 104.3; 2010: 286.1; and in 2014 at 401.6 billion. In 2014, GDP per capita at current USD was estimated at 42,522; and on the basis of international dollar (PPP) at 63,497 - putting the UAE in the world's $7^{\text {th }}$ rank.

While the laws stipulate that enterprises should either be wholly or majority-owned by UAE citizens (with the exceptions of micro enterprises operating in certain crafts and all enterprises in the free-zones), the majority of the enterprises are effectively owned by expatriates. To satisfy/go around the legal requirement, an enterprise fully or majority-owned by an expatriate is registered under the name of a local person (as owner or as majority shares holder), who receives a fee for this service as sponsor (locally called 'kafeel').
The last population census of 2005 (Ministry of Planning, 2007) makes available the total number of employers and self-employed (business owners), but the number is not segregated by nationality group (citizens and non-citizens). The 2009 Labour Force Survey (NBS, 2015) provides this classification as a percentage of all employed in the two respective groups. Using the two pieces of data, we can estimate the number of expatriate business owners at 77,969 and the number of local business owners at 4,820 (5.8\% of all business owners) in the last population census.

\section{Research Problem, Objective and Methodology}

That only $6 \%$ of business owners in any country are citizens and the rest are foreigners, poses enormous political and economic challenges to that country. In the UAE (as well as in the GCC region overall), major concerns raised were employment opportunities for the citizens and issues of economic sovereignty.

The UAE citizens (Emiratis) operating in the SME sector face fierce competition with the expatriates. Expatriates are more experienced and utilise own (same citizenship) networks within the UAE and in the country of origin. It is often the case that small entrepreneurs from a certain nationality or ethnic background, control a certain line of activity within a certain locality making it difficult for outsiders (citizens and non-citizens) to enter or to stay in the business (Haan, 2002, 2003). Wellpaid government and public sector jobs citizens enjoy entail a high transitional cost to move to the business sector. In addition, lack of business experience of young citizens, fee derived as 'kafeel' of businesses (without taking risk of the business) and lack of viable institutional support system to Emirati-owned SMEs play important roles in deterring (more) Emiratis to become, and succeed as, entrepreneurs (Haan, 2002).

The main objective of this paper is to establish and employ an empirical framework of SME institutional support system for the purpose of drawing a structure for the development of citizen-owned SMEs in the UAE. The framework may be useful to other countries in the GCC 
region (where citizens are minority, also in the SME sectors), and, being based on international experiences, may be informative elsewhere also.

The empirical framework advanced in the following section will be used for outlining what the paper considers as 'necessary interventions' for the development of Emirati SMEs and of Emirati entrepreneurship. What are considered necessary interventions will be identified through analysing the situation of Emirati entrepreneurs and of existing SME support organisations). Insights on how to intervene will be established using the benchmarking approach. Benchmarking and identification and transfer of best practices have been widely used in policy development (see, among others, Arrowsmith et al., 2004). Policy benchmarking is about assessing current situation against selected, relevant best practices. Singapore is selected as the main case for benchmarking (justification is given in section 2), in addition to allusions to other cases.

It is to be noted at the start that there is no unified definition of micro, small, medium and large enterprise in the UAE.

\section{Defining an Empirical Framework of SME Institutional Support System}

The role of the state in supporting SMEs, including areas and extent of this support, has been debated in the literature. The roots of the debate lie in the ideological differences between economic liberalism and state interventionism.

SMEs around the world are undoubtedly facing difficult situations, compared to larger enterprises, in many areas: access to finance, information, technology, markets, etc. There is a consensus that this unfavourable situation must be corrected, but the difference lies in whether the remedy should be by providing direct government support (e.g. access to finance at less than market rate; subsidised services, etc.) or indirect support. The liberalists argue that financial support (also in the form of subsidised services) leads to distortion of the market dynamics for the benefit of SMEs, which do not necessarily represent the suitable size for all activities, and may not be, contrary to common conviction, the effective sector for employment generation. They also think that receiving subsidies could lead to reluctance of SMEs to grow into larger enterprises (so as not to lose support), and thus compromise efficiency standards. They conclude that the role of the state can alternately be 'levelling the playing field' by removing obstacles facing SMEs, mainly lack of access to information, and by creating an enabling business environment for all enterprises (see for further discussions, Batra and Mahmood, 2003; Hallberg, 2000; Harvie and Lee, 2003).

On the other hand, evidence shows that in the success of a number of East and Southeast Asian countries, the state (selective) intervention in the economy, including massive support to SME development, has been instrumental (see, among others, Page, 1994; Pistor and Wellons 1999). It is also evident that in all industrial and in many emerging and developing economies an SME support system has been instituted. (Whether the system, in all these countries, is bringing coveted economic efficiency and growth and social equity, is another story, and requires a case-by-case analysis).

A main report prepared for OECD second SME Conference (OECD, 2004), establishes that one major lesson, independent of level of development or region, gained from global analysis of SME development is the need to have in place an SME strategy entrenched in the broader national development agenda; crosscutting with many areas, like macroeconomic policies, micro economic business environment, good governance, infrastructure, education, health, etc. Strengthening SME sector's competitiveness requires an enabling regulatory and administrative environment, access to finance, development of human and natural resources, supporting infrastructure, SME capacity building, strengthening SME-FDI linkages and improving aid effectiveness. Providing a review of SME institutional support structure of four selected countries (two industrial, USA and UK, and two developing, Philippines and Thailand), the Report 
manifests that in all four, the system of institutional structure encompasses three levels; national, regional and local. The government finances or supports the financing of all these structures. All of these countries provide direct support to SMEs through various programmes.

Another report, prepared for European Commission, on reforming institutional support systems for SMEs in EU Candidate Countries, recommended the following measures: 1formulating medium-term SME development strategies; 2- improving the business environment; 3- supporting the development of coherent National Business Support System (for provision of consistent and effective support services) ; 4enhancing access to finance (non-banking loans, equity and venture capital; bank guarantee) and 5strengthening entrepreneurial skills (EMS, 2002.)

The Global Alliance of SMEs (GASME, 2015), on the basis of global experience of SME development support, identifies four major areas that constitute the support system. The first is establishing a complete legal system in the form of general and/or specific SME laws and acts. The second is creation of sound and efficient government institutions for SME support. These include institutions at various levels, from national to local, entrusted with regulatory, administrative and facilitation roles. The third area is financial support. This comprises credit guarantee mechanism, direct funding by not-for-profit organisations, establishment of venture and private equity market and facilitating access to capital market financing opportunities. Establishing a diversified non-governmental service system to compliment the government's role represents the fourth area. The nongovernment system encompasses NGOS, trade associations and private sector, and offers a wide range of professional services to SMEs.

In India, SME support system has been focusing on four main areas: technology, marketing, finance and skill development. A host of institutions form the technology support infrastructure; the Small Industries Development
Organisation and the Small Industries Service Institute being the main actors. These two institutions also play a major role in extending marketing support to SMEs; assisting them to participate in national and international bulk tenders and to reach to international markets in other ways. Small Industries Development Bank of India (SIDBI) has been created as a specialised financial institution. In addition to direct lending, SIDBI also refinances other financial institutions that lend SMEs. The Ministry of MSME of India has established a range of institutions to provide skill development programmes. In India, the umbrella organisation for SME support is the Office of Commissioner-Micro, Small and Medium Enterprises (Export-Import Bank of India, 2009).

The Small and Medium Enterprise Business Administration (SMBA) is the principal SME institution in Korea, with 11 regional offices and 3 branches. Current focus of Korea's SME support system can be summarised as follows. 1Fostering creation of new start-ups, especially technology-based, through improving business environment for them, provision of information, enhancing youth entrepreneurship and expanding the management capacity and safety network of microenterprises; 2- Removing obstacles facing growth of high potential SMEs (including availability of trained human resources geared toward the needs of SMEs), and enhancing an enabling environment for the development of creative and innovative SMEs; 3- Expand the range of financial solutions, including venture capital, and facilitating access to them; 4Enhancing the market base of SMEs through advancing export capacity and expanding local demand for SME products; ; and 5- Creating conditions for fair trade to protect SMEs, and promote business linkage between large enterprises and SMEs (SMBA, 2015).

The challenges facing SME support system in Hong Kong, as has been viewed by Trade and Industry Department (2012), consist of the following areas. 1- Maintaining favourable business environment; 2- Expanding the range of 
financial solutions, including loan guarantee scheme, and enhancing SME knowledge about them and about financial management; 3Drawing up of guidelines on corporate governance for SMEs in collaboration with professional and trade associations, and fostering strategic partnership between SMEs and large enterprises; 4-Increasing supply of well-trained human resources; 5- Fostering application of technology and raising SME IT awareness; and 5Facilitating expansion of international markets (establishing SME Export Marketing Fund) and growth of local and Mainland markets.

On the basis of the brief reflections on international experiences portrayed above, the empirical framework of a comprehensive institutional system for SME development is comprehended in this paper to consist of the following four pillars:

- Legislations, enabling environment and policy advocacy;

- Finance and financial Services;

- Business development services (BDS); alternatively referred to as non-financial services;

- Networking and business linkage.

Each of these pillars is understood to include relevant supporting legislation and/or policies, institutions and programmes.

While different countries face different challenges, opportunities and options, this empirical framework may be appropriate as a general approach for analysing and developing SME support systems. The specific policy and functional issues addressed in this paper could be of special relevance to other GCC countries.

The case of Singapore, which serves as a case for benchmarking, is presented on the basis of the empirical framework this paper advances.

\section{SME Institutional Support System in Singapore}

Singapore's SME institutional support system has been selected for benchmarking for the following reasons. While Singapore's SME system is not targeting minority citizens, it has been supporting an SME sector in a small country surround by relatively larger ones. Singapore is a prominent case of successful government intervention in the economy, and its SME institutional support system, only 30 years old, is regarded as one of the world's most comprehensive systems, from which other countries (emerging and advanced alike) have been learning. For policy makers in the UAE, selecting Singapore for benchmarking could be appealing as a number of government institutions take the Singaporean government system as a model to be followed. It is to be noted that Singapore's public sector performance has been consistently, and for many years, ranked as number one or two world-wide by the World Competitiveness Report. For the year 2015/16, the Report places Singapore in the second place in the general global competitiveness index (World Economic Forum, 2015).

SMEs in Singapore (180,000 in number) comprise $99 \%$ of all enterprises, contribute nearly half of the GDP and employ $70 \%$ of the workforce (SPRING Singapore, n.d.).

\section{Legislation, Enabling Environment and Policy Advocacy}

Singapore has undergone major economic structural transformations. Upon independence in 1965 , it was a country with no natural resource, confronted with high level of illiteracy and widespread unemployment. At the beginning of the Millennium, Singapore has transformed into one of the world's fastest growing economies.

Liang (2007) summarises the evolution of Singapore SME strategies as follows:

- 1965-85: The economic policy (spearheaded by the Economic Development Board-EDB) was focusing on industrialisation through attracting MNCs. SME development was not specifically targeted.

- 1986: The new economic policy document entitled "Singapore Economy: New 
Directions" highlighted the need for developing SME policies and interventions. The EDB established a special SME unit.

- 1989: First SME Master Plan was launched.

- 2000: Second SME Master Plan (SME 21) was released.

Unlike some other Asian countries (e.g. Japan and Korea) that have preceded Singapore in developing comprehensive systems for SME support, Singapore has opted to start with a plan and not SME law or act.

The 1989 SME Master Plan came as result of recognition, incited by the 1985 recession, that local SMEs' role cannot be relegated to providing support functions to the MNCs. SMEs are a vital constituent of Singapore's future economic development (Soon, 1994).

The 1989 Plan was a comprehensive and a detailed document of programmes and actions to create an enabling environment for the SME sector to become a capable player in facilitating economic growth and transforming Singapore into a newly industrialised economy. The Plan focused on: 1- promoting domestic entrepreneurship, technology adoption and innovation, 2-enhancing information exchange on new methods and opportunities, including finance, business planning and human resource management, 3facilitating access to training and consultancy services and promoting and transferring best business practices to enhance growth and improve productivity, and 4-encouraging SMEs to grow internationally (Liang, 2007; Teng, 2011).

Building on the First SME Master Plan, SME 21 'Positioning Singapore for the $21^{\text {st }}$ Century" envisions the creation of an SME sector which is 'a source of entrepreneurship and innovation; a base of strong supporting industries and strategic partner for foreign SMEs and MNCs; manufacturer of high-value added products, global provider of professional services; robust domestic service sector enhancing the quality of life in Singapore' (cited in Wei-Yen, 2004, p.183). It is to be noted that SME plans/strategies in Singapore are continuously being reassessed during implementation, and changes and/refinements are introduced when necessary.

In Singapore SME support system, the two most prominent actors are the Ministry of Trade and Industry (MTI), at the level of strategies and policies, and SPRING Singapore, at the level of policy advocacy and support programmes. Other specialist and functional organisations are also constituents of the structure.

SPRING Singapore started as the National Productivity Board (under MTI) with a mandate not focusing only on SMEs. In 1996, it merged with related functions of EDB (including SME Unit) to form the 'Productivity and Standards Board' (PSB). Then, after SME 21 was released, which focused on growth and innovation, PSB was renamed as SPRING 'Standards, Productivity, Innovation and Growth' (Liang, 2007). SPRING is considered the paramount institution for SME support in Singapore.

\section{Selected Finance and Non-Financial Service Programmes}

Unless mentioned separately, the below draws on the website of SPRING (Spring Singapore, 2015).

\section{Finance}

A wide range of SME finance options are available both for start-ups and established enterprises. SPRING SEED is the investment arm of SPRING Singapore. It finances start-ups though two major schemes. SEED runs the equitybased co-financing option geared toward innovative start-ups that have strong international growth potential. Another co-financing scheme is the Business Angel. Start-ups that are able to attract investment interest from any of the business angel investors can apply for similar investment from SPRING SEED. Both the angel investor and SEED then become equity holders in the company.

SPRING and others organise business project competition among school and junior college 
students with the aim of building and enhancing business capabilities. The YES! Schools programme offers funding for the winning projects. In this way, the programme contributes to creating new start-ups.

For established enterprises, one important source of finance is the Local Enterprise Finance Scheme. The scheme offers credit of up to $S \$ 15$ million for SMEs owned by Singaporeans. The Micro Loan Programme provides credit of up to $\mathrm{S} \$ 100,000$ for micro enterprises (10 or less workers) owned by Singaporeans. Established companies also benefit from the Over-the-Counter Capital (OTC); which is a trading platform for unlisted companies to raise capital through selling shares (see the website of MAS- Monetary Authority of Singapore).

Start-ups and established companies may benefit from the Loans Insurance Scheme, which insures loans against default risks. Premium is paid by the government and the SME.

\section{Non-Financial Services}

SPRING assists SMEs capability development mostly through financial subsidies. The Capability Development Grant covers up to 70 percent of cost of capability enhancing. Innovation \& Capability Voucher (of $\$ 5,000$ value) is given to encourage SMEs taking first actions in developing their capability. Companies investing in enhancing productivity and innovation can be offered grant in form of tax deduction.

Private sector providers deliver the capability enhancing programmes (training, consultation, etc.) that SMEs may demand using the grants offered by SPRING. SPRING also subsidises private sector incubators by offering them up to $70 \%$ grant to elevate their capabilities to assist start-ups.

Another route SPRING uses to raise SME capabilities is through the Online Toolkits; which are means for enterprises to evaluate their strengths and weaknesses and develop solutions. Toolkits cover areas of customer service, financial management, marketing and productivity.
Technology innovators may lack the ability to commercialise their inventions. The Technology Enterprise Commercialisation Scheme assists start-ups with persuasive technology intellectual property to commercialise their projects.

Since the First SME Strategy, Singapore has been encouraging the internationalisation of SMEs. The Enterprise International Singapore furthers international presence of SMEs through provision of capacity development programmes, funding participation in external trade fairs and helping them to access finance. It has also set an office in China to assist SMEs entering the Chinese market (Enterprise International, 2015).

Enhancing productivity of SMEs through use of technology has been another focus of Singapore SME strategy. Infocomm Development Authority (IDA) is regarded as the Government Chief Information Officer. Its mission is to identify and facilitate adoption of ICT generally. In 2010, iSPRINT programme was established to boost SME adoption of ICT technology (IDA, 2015).

\section{Networking and Business Linkage}

The two entities that serve most the networking needs of SMEs are the Association of Small and Medium Enterprises (ASME) and Trade Associations and Chambers (TACs).

ASME was established in 1986 as a not-for-profit organisation of SMEs with the aim of promoting a more conducive business environment which facilitates starting, growth and development of SMEs. ASME is a major representative of, and networking venue for SMEs. It disseminates information to its members and organise regular networking events that facilitate business linkages (ASME, 2015).

Six TACs have been established: Association of Singapore Marine Industries, Print and Media Association, Restaurant Association of Singapore, Singapore Business Federation, Singapore Food Manufacturers' Association and Singapore Furniture Industries Council. TACS are important settings for reaching out to SMEs to share information on new industry developments and 
opportunities, as well as making them aware of the opportunities the government offers for SME support (The Business Times, 3 June 2015, cited in $\quad$ www.ie.singapore.gove.sg/Media.Centre).

TACS enter into partnership with SPRING to develop specialised clusters. Clusters, as is known, offer enterprises immense opportunities to improve productivity raise competitiveness and cooperate in many other ways.

From another side, The Business Angel programme (and other similar programmes) coordinated by SPRING, and the OTC platform organised by Monetary Authority of Singapore provide SMEs with opportunities to link with potential investors/entrepreneurs.

The Singaporean SME development experience offers many lessons from which the Emirati SME support system could learn.

\section{Toward Establishing Emirati SME Institutional Support System}

This main section starts with a review of the situation of Emirati SMEs. A brief note on the need for intervention will precede the discussion on pillars of the institutional support system.

\section{Emirati Entrepreneurs: A Brief Situational Analysis}

The first published works on SMEs in UAE (Rettab, 2001- based on a sample survey of SMEs drawn from various sectors and emirates- and Baud and Mahgoub, 2001- investigating women's employment opportunities) were carried out within a project by the Ministry of Labour in 1999 to develop a strategy for the development and employment of the Emirati labour force. The Ministry's project resulted in the establishment of TANMIA- the National Human Resource Development and Employment Authority (see Abdelkarim, 2001/b). It is within TANMIA's Centre for Labour Market Research and Information (CLMRI) that the first studies focusing on Emirati entrepreneurs- based on small surveys and in-depth interviews providing quantitative and qualitative insights- were concluded. These studies (Haan, 2002, 2003,
2004) stand out to date as the most informative on the subject, and they served as advocacy for the need to intervene in support of Emirati SMEs. Following them, works based on interviews with Emirati entrepreneurs that are relevant to this paper are scarce, and include reports of GEM (Global Entrepreneurship Monitor). These reports target both Emiratis and expatriates (El-Sokari et al., 2013). The review below draws on CLMRI and GEM studies.

Emirati entrepreneurs raised the initial capital for their new businesses mainly through personal sources $(59 \%)$, through family $(12 \%)$ or through banks $(22 \%)$. Major activity is trade, which represents a historical continuation of the Emirati business profile, followed by services and, to a less extent (1 in 7), industry (Haan, 2002). When seeking business advice, before and after establishing their businesses, Emirati entrepreneurs rely more on social (family and friends) than on external advisory (professional and market) networks (Haan, 2003 and El-Sokari et al., 2013).

Majority of Emirati business owners (80\%) were in full-time (mainly government) employment during and after establishing their business. Secured and lucrative government jobs are difficult to leave in order to take up (insecurities of) private business (Haan, 2002 and El-Sokari et al., 2013). With the relative ease of importation of labour, it can also be added; Emirati entrepreneurs can easily find experienced, low cost expatriates as full-time operation or general managers of their businesses. The Emirati entrepreneur's role would be general supervision. This sounds a rational decision when engaging in business is considered as a source of extra income, and not the sole source of livelihood.

The major problems Emirati entrepreneurs faced after establishment were: 1- competition with other owners, especially expatriates who get support through their networks, 2- finance, 3marketing and 4-lack of institutional support. They believed that their success chances were low or very low $(55 \%)$ or fair or good $(45 \%)$ (Haan, 
2002). Emirati businesswomen's particular problems are: 1- securing institutional funding, 2lack of previous experience in business, 3handling government procedures, and 4- in some cases, lack of support of husbands and/or family (Haan, 2004).

To the question why UAE citizens are reluctant to enter into private business in larger numbers, the answers were as follows: "not used to this kind of experience with unknown outcome"; "lack of capital to start the project"; "lack of institutional support to Emirati SMEs", and "low rate of return to investment" (Haan, 2002). It should not be understood that Emiratis' entrepreneurial activities are relatively lower than the expatriates'. As per GEM's measurement of Total Entrepreneurial Activity-TEA (a category consisting of nascent entrepreneurs and new entrepreneurs less than three and a half years in business) of Emiratis was $10.4 \%$ of Emirati adult population in 2011; which is higher than the rate of expatriates; 5.6\% (El-Sokari et al., 2013). However, it should also be noted that the opportunities (both legal and financial) for Emiratis to engage in business are higher. In addition, the overwhelming majority of adult expatriates come to the UAE (and have a legal status) as wage earners, if we exclude accompanying family (to note: only a very small segment of expatriates is allowed to bring family).

Emiratis also surpass expatriates in the rate of business discontinuation: $4.5 \%$ against $2.2 \%$. Main reasons stated were 'personal reasons' (35.8\%) and business 'non-profitable' (32.3\%). By gender, the reasons varied considerably: $50.7 \%$ of Emirati men attributed closing business for 'business not profitable' (against only 14.3\% of women), and $66.7 \%$ of the women stated 'for personal reasons' (with only $12.4 \%$ of men). The GEM report commented that cultural pressures (familial commitments) could be the reason for the high incidence of 'personal reasons' among women (El-Sokari et al., 2013).

\section{The Need for a Support System}

Supporting the development of the entire SME sector in UAE is vital to growth and diversification of the economy (and the need for this will be highlighted below). However, our main concern here is the development of a system of institutional support for Emirati entrepreneurs. The need for such a system is justified by the following.

1. They represent a minority engaged in a sector mostly dominated by expatriates and face fierce and inequitable competition. Expatriates gain their competitive advantage by using strong networks along ethnic/nationality lines, which enables them to cooperate with each other and with larger enterprises within the same network inside the UAE and in the countries of origin (Haan, 2002, 2003). In this way they get support not only in accessing markets and finance (also nonbanking loans), but also by benefiting from the experience of older and/or larger enterprises.

2. Competition with expatriates often causes higher rate of business discontinuation among Emirati SMEs (double the expatriates' rate).

3. Citizens entered many business activities relatively late (historically trade constituted the main area of activity of Emirati businesses, and still is).

4. A system supporting Emiratis in business ventures helps diversifying their opportunities for economic participation and enables them to actively engage in formulating future directions of their national economy.

\section{Enabling Environment, Legislation and Policy Advocacy}

The SME legislative scene in the UAE witnessed a major development. In April 2014, a federal SME Law was signed, objective of which is to encourage Emiratis to run SMEs. The law identified Emirates Development Bank, established in 2011 (with a capital of AED 10 
billion to help boost economic development) to provide government funding ( $40 \%$ of its assets) to Emirati SMEs. The Law called for the formation of SME council. It also stated that government entities and companies, in which the government owns more than $25 \%$ of the total capital, are to contract with Emirati SMEs by at least 5\% of the total value of their contracts. Listed companies are called upon to follow suit (The National, 13 April 2014).

It should be noted that in their pursue of creating enabling environment for SME development, countries may use laws and acts as legislative tools and translate them into policies and programmes, implementation of which is entrusted to specialist institutions. In Japan, for example, the Small and Medium Enterprises Basic Law was issued in 1954. This was followed by other subsidiary legislations, such as the Financial Assistance Act, in addition to a large number of policies and regulations, formulated when necessary to enhance SME development in different stages/situations (Ituh and Urata, 1994). Other examples are the USA Small Business Act (1953), Korea Small Business Law (1966) and Indonesia Small Enterprise Act (1995), to mention only some.

In the UAE, the SME Law and the creation of SME Council are positive initial steps. SME laws are generally basic pointers and serve as a receptacle for further course of action (acts targeting specific areas, strategies, policies, programmes, etc.). It is the responsibility of the UAE SME Council, specific responsibilities of which have not yet been formulated (personal communication from a Council member in November 2015), to lead further actions. On top of the Council agenda is the formulation of a strategy. It is important to emphasise that a strategy for the development of Emirati-owned SMEs, that aims to be effective and sustainable, cannot be advanced without the presence of enabling environment for the development of the entire country's SME sector. Emirati SMEs simply cannot flourish if the business environment for SMEs in the country is not conducive and when economic conditions for growth are lacking. The specific strategy (or plan) to enhance participation of Emiratis in the SME sector is to be linked to a strategy for enhancing the business environment for development of the country's SME sector. The requirements of this have never been thoroughly researched before.

The Emirati SME- focused strategy should identify the specific areas in need of intervention and specific plans linked to these areas; as well as plans for strengthening of existing and establishing of new support institutions -as required- that can be assigned the implementation of the plans set for each intervention area identified. Singapore SME strategies; identifying challenges, opportunities and priorities, and on their basis formulating intervention programmes, offer a lot to learn from.

Emirate-level SME support institutions exist in all seven emirates. They work without a countrylevel coordinating mechanism, lack of which hampers their effectiveness and efficiency. UAE is a small country, and some emirates are very small population- and economic activity-wise. Support programmes devised may often lack the critical mass of beneficiaries. The UAE SME Council, having representation of all emirates, is to address this issue.

One issue that transpired above is that the majority of Emirati entrepreneurs are full-time wage employees, predominantly in the government sectors (federal or emirate-level). For the same level of experience and qualifications, Emiratis receive higher wage than expatriates in the government, and what they receive in the government is mostly (much) higher than what they would have received in the private sector (Abdelkarim, 2004; Haan, 2002). In addition to labour market imbalances that might have been created, this situation will continue to feed the thinking among many/majority of Emiratis that business venturing is only a source of extra income. It is of course rational to think in this way; enjoy benefit of relatively high wage and secure employment and avoid insecurities of 
business ventures. However, such situation ('halfheartedness) will make it difficult to advance Emirati entrepreneurship; create a generation of innovative entrepreneurs. One idea that floated in the past is to compel government funding recipient entrepreneurs to focus full-time on the enterprise, and, at the time, grant them the opportunity to return to the government job within a certain number of years. Another, that the author of this paper has been propagating, is that while governments have the right to directly and indirectly (re)distribute part of the national wealth to their citizens, this should not be achieved in the form of topping wages, which distorts labour market functioning as well as negatively affects work ethics. Such 'reward' should be based on citizenship, not wage employment, and in this way all eligible citizens receive it regardless of economic activity. It can of course be regulated in a way to enhance social equity; less or no reward for the high- income categories, and vice versa. Working on such a scheme is long term, but so is building a robust national SME sector (and realise sustainable socio-economic development).

\section{Finance and Financial Services}

The first SME finance project in the UAE was AlTomooh (means ambition) established by the then Emirates International Bank (now Emirates National bank of Dubai) in 1998. Up to 2013, 130 Emirati-owned projects, mostly in Dubai, had been granted loans for a total of 60 million Arab Emirates Dirhams (1 USD $=3.65$ AED $)$ (AMEinfo.com, 18 March 2013).

SME institutions (supporting Emiratis) have been established in all emirates, as mentioned earlier. The two most important ones are based in Abu Dhabi and Dubai (the two major emirates, between which most of the GDP is produced).

The first SME- organisation in UAE was founded in Dubai in 2002; Mohammed bin Rashid Establishment for SME Development, commonly known as Dubai SME. Dubai SME until recently was not providing direct finance and was only assisting SMEs to access bank funding. Recently, CEO of Dubai SME announced launching of a new fund with assets totalling AED 600 million. The Fund offers innovative Emirati SMES based in Dubai emirate two types of loans; 1-Seed Capital loan- offered directly to start-ups in the range of AED 50,000 to 500,000, and 2- Credit Scheme Loan for both start-ups and existing enterprises requiring a fund of AED 500,00 to 5 Million (WAM Emirates News agency, 12 April 2015).

Khalifa Fund was established in 2007 by Abu Dhabi government to help develop Emirati SMES, especially, but not exclusively, in Abu Dhabi emirate. Currently, capital available to it is AED 2 billion. Funding programmes include: Bedayaoffers to start-up loans up to AED 3 million; Zeyada- under this programme established enterprises may receive up to AED 5 million for expansion; Tasneea- earmarked for industrial enterprises for amount up to AED 10 million; Khutwa (microfinance; loan up to Dirham 250,000)- directed primarily at home-based businesses and is social in nature targeting special groups (divorced women, widows, etc.). In addition, the Fund finances 'social outreach' programmes (for Emiratis with special needs; inmates and former drug addicts) (Khalifa Fund, 2015).

None of the two organisations publish periodic reports on operations. So, it is not possible to assess the scale and reach of funding activities.

The Emirati-dedicated SME finance scene may be summarised as follows: Khalifa Fund represents the only SME organisation with serious funding available to it. Dubai SME is beginning to have its own source. Websites of SME organisations in other emirates do not indicate presence of dedicated SME funds. The experience of Singapore (and other countries) in creating a wide range of SME financial solutions, may be informative in seeking additional sources.

The UAE enjoys a wide network of banks, many of them with SME finance programmes. But these banks require collateral for the provision of finance, which most of SMEs cannot provide, especially the start-ups. Some countries (e.g. 
India) through its Central bank oblige banks to allocate a certain percentage of their loan portfolio to SMEs ((Export-Import Bank of India, 2009). Many other countries (e.g. Singapore) opt for establishing loan insurance programmes. These programmes may also support loan interest and negotiate grace periods (for analysis of some international experiences, see OECD, 2013). The establishment of loan guarantee programmes in the UAE can ease the burden on government funding. It is to be noted that Dubai SME has a beginning in loan guarantee system. The Emirates Development Bank (now assigned as the principal Emirati SME funding institution) may want to include a loan guarantee scheme in its range of financial services.

Private venture capital may be raised through Over-The-Counter (OTC) capital markets. OTCs raise capital for existing or start-up companies with growth potential. In addition to Singapore, OTC capital markets function in other countries. In Korea, for example, KONEX, part of Korea Exchange, focuses on raising venture capital for promising start-up SMEs (see website of KONEX). When the Emirati SME sector has been assessed as reaching a certain maturity level, OTC market can be initiated. In addition to raising funds, venture capital may have non-financial benefit; it can contribute to strengthening the management capacity of the SMEs, as they can take advantage of the knowledge of more experienced investors partnering with them. In the same way, the Business Angel scheme of Singapore can be replicated. That a business angel investor is willing to invest in a start-up, could be a strong indication to the SME funding agency of the viability of the project.

\section{Business Development Services (BDS)}

In addition to funding opportunities, SMEs require services in other areas: access to information, management and technical capabilities, marketing, access to technology, etc. All these non-financial services are included under the notion of Business Development Services (Committee of Donor Agencies, 2001).
After tens of years of experience in supporting SMEs in the developing countries through BDS programmes run directly by governmental or nongovernmental organisations, the system has been judged by the Donors Committee as inefficient; reaching only a limited segment of the SMEs and marred by bureaucracy and corruption (for a detailed historical account of Donors' experiences, see Levitsky, 1996). The option that seems to come across was to consider moving to the "market development model", which means letting private sectors provide BDS, while governments and donors develop the market for BDS.

Government SME organisations supporting Emirati-owned SMEs provide some BDS, mainly at the start-up phase. Though Dubai Entrepreneurship Academy and incubation centre, Dubai SME assist start-ups to gain business knowledge (Dubai SME, 2015). Khalifa Fund organises capacity building programmes (face-toface and on-line) to the Fund members, for both start-ups and established SMEs (Khalifa Fund, 2015). It is not clear whether these services are provided directly by the organisations themselves or through private providers.

Three major issues face policy makers in the UAE in the search for efficient BDS system.

1. Providing BDS entirely through dedicated public institutions run the risks of inefficiency that the international literature has been warning about.

2. The market for private BDS currently seems to be weak (the cause in the first place is deemed to be demand-deficiency, as in an open economy like the UAE, it will not be difficult attract viable providers, if sufficient demand arises). This market needs to be developed as a first step.

3. Emirati SMEs comprise a very small segment of the SME sector (in a small country). To develop a BDS market covering all areas, and based on the needs 
of Emirati SMEs alone, will be a difficult and costly undertaking.

The solution may be to develop a BDS market (expanding both the demand and the supply sides) to serve all businesses, with Emirati SMEs organisations (as per their mission) providing support to Emirati citizens. Developing a viable BDS market helps to enhance capabilities, productivity and innovation of the entire SME sector in the UAE which, as has been mentioned earlier, is a necessary condition for sustainable growth of the economy and of Emirati-owned SME enterprises themselves.

Governments in countries with SME support systems tend to be actively involved in information collection and dissemination as an important condition for creating a market for BDS. Information is provided usually by specialised information centres (public mainly, but also private). The information provider acts as an intermediary between enterprises and BDS providers. It provides information to service providers regarding the needs of SMEs, and to users about the available services and their benefits. It is important that a UAE government organisation to assume a leading intermediary role.

Providing information on BDS, negotiating with providers and grouping of Emirati beneficiaries to avail of the services can be assumed by the existing SME organisations, which may also offer advice on other matters, like government regulations, access to finance, etc. through 'onestop centres', that exist in a number of countries. In organising BDS support for Emirati entrepreneurs, two methods, among others, may be used. 1- SME organisations may contract private providers to deliver the services to their beneficiaries, with the beneficiaries receiving this service free of charge or in a subsidised cost. 2Introduce use of the voucher system. The voucher system is especially useful for established enterprises, which are more capable of identifying their specific needs and of selecting providers, and, at the same time, may offer them the opportunity, while using the service in a group, to mix/network with expatriates with different backgrounds and experiences.

\section{Networking and Business Linkage}

Findings of CLMRI and GEM studies referred to above reveal that Emirati entrepreneurs lack effective, institutional networking. They mainly depend on social networks (family and friends) in getting business information and hardly there is any coordination of business activities among them as groups.

Examples of temporary networks in the UAE are to be found in Khalifa Fund and Dubai SME. Members are occasionally invited to attend special events. UAE Businesswomen Councils, structured at UAE- and emirate-level, and include citizens and expatriates, follow the same pattern of networking (Emirate Businesswomen Council's website).

Creating permanent communication channels/networks among the Emirati SME owners, is a task of high significance. Global experience has shown the advantages of these networks, not only to support SME business development through sharing of information and experience, but also to make their voices heard by, and enable them to coordinate with their institutional surrounding (Bennett and Ramsden, 2007).

Such permanent networks in the form of associations can be geographic and may be further segmented by specific business activities. Initially, such organisations may be created at the level of individual emirates, and at a later stage they can evolve into a networking relationship across emirates, creating permanent networks in the form of functional associations and a national one. The SME council can contribute to establishing such associations in cooperation with emirate-level Chambers of Commerce and Industry and existing SME support organisations.

Another form of networking is when groups of SMEs come together to strengthen their competitive position to achieve economies of 
scale; by, for example, obtaining bulk purchase of input, meeting large orders and benefiting (for less cost per firm) from capacity building programmes. This horizontal networking also allows SMEs to enhance their strategic management and innovation capacities by learning from each other and taking collective decisions. Vertical networking/business linkage occurs when the enterprise specialises in its core business and subcontracts other related activities to another firm/other firms. This may ensue between SMEs or between large enterprises and SMEs. Vertical and horizontal networking is often facilitated within clusters. UNIDO (2001, p.9) defines clusters "as sectoral and geographic concentrations of enterprises that produce and sell range of related or complimentary products and, thus, face common challenges and opportunities". Such clusters open business opportunities for specialist suppliers, bulk traders and service providers. Clusters emerge in all countries mostly naturally, but also through enterprise selforganisation and through government facilitation. The SME Council, with economic development departments and chambers of commerce and industry, may take initiative in facilitating creation of technology-based clusters. May be such clusters are not be dedicated to Emirati SMEs only; relevant expatriate-owned enterprises may be included. Experienced expatriate technology entrepreneurs working in the same clusters with Emirati SMEs would facilitate knowledge transfer, enhance collective learning and may provide desirable complementarity in activities of such clusters.

Opportunities for expanding business linkages between Emirati SMEs and large enterprises could be facilitated by the SME Law, which entails government companies (and those in which the government owns more than $25 \%$ ) to allocate a certain percentage of their contracts to SMEs. This may evolve into large companies 'adopting' certain SME suppliers and subcontractors. Such linkage could encourage large companies to take interest in improving productivity of their SME suppliers/subcontractors. Japanese conglomerates, among others, are good example of this.

\section{A Concluding Note}

The fact that citizens in UAE comprise only $6 \%$ of the business owners in the country, together with a situation in which young men and women are facing difficulties in finding employment, have put a lot of pressures on the government to take actions. Recently, the government enacted the Small Business Law and established UAE SME Council. This step has created the vessel for establishing a comprehensive institutional support system for the development of Emirati-owned SMEs. Government intervention supporting the SME sector (in various ways) is a global phenomenon, and may be even more essential in the conditions of empowering a minority. This paper contributes to the establishment of such a support system. However, it is important to emphasise that Emirati SMEs may not grow in a sustainable manner if conditions for growth of the entire SME sector are lacking. Hence, the first step is to promote an enabling environment for the development of the country's overall SME sector. This is to be followed by, or concurrently accomplished with, enhancing support structures for advancing Emirati SMEs. Building up a UAE country SME development strategy, in addition to elaborating on the constituents of the strategy to support UAE citizens, remain areas for further research.

\section{Cited References}

[1] Abdelkarim, A. (Ed.) (1999). Change and Development in the Gulf. London: Macmillan,

[2] Abdelkarim, A. (2001/a). UAE Labour Market and Problems of Employment of Nationals: An Overview and Policy Agenda. Research Report No.1. Dubai: Centre for Labour Market Research and Information.

[3] Abdelkarim, A. (Ed.) (2001/b). Employment and Employability in a Small Economy- The UAE. Maastricht: Shaker.

[4] Abdelkarim, A. (2004). Toward a Strategy for Enhancing Wage Employment of UAE Nationals in the Private Sector: 
Employment and Human Resource Report (Part One). Dubai: TANMIA.

[5] Asian Development Bank (2014). Asia SME Finance Monitor 2013. Mandaluyong City: Asian Development Bank.

[6] Arrowsmith, J., Sisson, K. and Marginson, P. (2004). What Can Benchmarking Offer the Open Method of Co-ordination?. Journal of European Public Policy, 11(2), pp. 311-328.

[7] Batra, G. and Syed, M. (2003). Direct Support to Private Firms: Evidence on Effectiveness, World Bank Policy Research Working Paper No. 3170. Washington DC: World Bank.

[8] http://ssrn.com/abstract=636589.2003 (Accessed September, 2015).

[9] Baud, I. and Mahgoub, H. (2001). Towards Increasing National Female Participation in the Labour Force: Research Report No.2. Dubai: Centre for Labour Market Research and Information.

[10] Beblawi, H. and Lunciani, G. eds. (1987). The Rentier State. London: Croom Helm.

[11] Bennett, R. and Ramsden, M. (2007). The Contribution of Business Associations to SMEs: Strategy, Bundling or Reassurance?. International Small Business Journal 25(1), pp.49-76.

[12] Committee of Donor Agencies (2001). Business Development Services for Small Enterprises: Guiding Principles for Donor Intervention. Washington D.C: Committee of Donor Agencies for Small Enterprise Development. Secretariat -World Bank.

[13] www.enterprisedevelopment.org/download.ashx?id=1291 (Accessed September, 2015).

[14] DUBAI SME (2011). The Role of Government in Supporting Entrepreneurship \& SME Development. Dubai: Mohammed Bin Rashid Establishment For SME Development.

[15] El-Sokari, H, Van Horne, G, Huang, Z-Y and Al Awad, M. (2013). GEM UAE Entrepreneurship- An Emirati Perspective. Dubai: The Institute for Social and
Economic ResearchZayed

University.www.gemconsortium.org (Accessed September, 2015).

[16] EMS (2002). Ad Hoc Report on SME Development. Assessment of the European Phare Programme. Brussels: European Commission.

[17] http://ec.europa.eu/enlargement/pdf/financ ial_assistance/phare/interim_s_zz_sme_01 002_en.pdf (Accessed March, 2016).

[18] GASME (2015). Four Global Experiences to Support SMEs. New Jersey: Global Alliance for SMEs.

[19] http://www.globalsmes.org/news/index.ph p? func $=$ detail $\&$ lan $=$ en $\&$ detailid $=945 \&$ cata $\log =03$ (Accessed August, 2015).

[20] Hallberg, K. (2000). A Market-Oriented Strategy for Small and Medium-Scale Enterprise: Discussion Paper No.60. International Finance Corporation. Washington DC: The World Bank,

[21] Haan, H. (2002) Report on A survey Among National Small and Medium Enterprises: Research Report No. 6. Dubai: Centre for Labour Market Research and Information.

[22] Haan, H. (2003) Business Networking for SME Development in the UAE: Research Report No. 12. Dubai: Centre for Labour Market Research and Information.

[23] Haan, H. (2004). Small Enterprises: Women Entrepreneurs in the UAE: Research Report No. 19. Dubai: Centre for Labour Market Research and Information.

[24] Harvie, C. and Lee, B.C. (2003) Public Policy and SME Development: WP03-18 Economics Working Papers Series. Wollongong: Department of Economics University of Wollongong Research online, Wollongong. http://www.uow.edu.au/commerce/econ/w papers.html (Accessed September, 2015).

[25] Levitsky, J. (1996) Support Systems for SMEs in Developing Countries-A Review, UNIDO Small and Medium Enterprise Programme, Vienna. http://www.unido.org/fileadmin/import/32 
888_SupportSystemsforSMEsinDevelopin gCounties (Accessed July 2015).

[26] Liang, T. W. (2007) 'SME Development in Singapore: Of Entrepreneurship Infrastructure and SME Strategy', in Pacific Economic Cooperation Council and Chinese Taipei Pacific Economic Cooperation Committee, The Policy Environment for the Development of SMES, Singapore, pp. 191-225).

[27] Ministry of Planning (2007) UAE 2005 Population Census, Ministry of Planning, Abu Dhabi.OECD (2004) 'Promoting SMEs for Development'. Paper presented at OECD Second Conference of Ministers Responsible for Small and Medium-Sized Enterprises, Promoting Entrepreneurship And Innovative SMEs In A Global Economy: Towards A More Responsible And Inclusive Globalisation, 3-5 June, 2004, Istanbul, Turkey. http://www.oecd.org/cfe/smes/31919278.p df (Accessed March, 2015).

[28] Page, J. (1994) 'The East Asian Miracle: Four Lessons for Development Policy', in S. Fischer and J. Rotember (Eds.), NBER Macroeconomics Annual 1994- Volume 9, National Bureau of Economic Research, Cambridge MA, pp.219- 282.

[29] Pistor, K. and Wellons. P.A. (1999) The Role of Law and Legal Institutions in Asian Economic Development, 1960-1995, Oxford University Press, New York

[30] Rettab, B. (2001) 'Employment Creation through Small Enterprise Development', in A. Abdelkarim (Ed.), Employment and Employability in a Small Economy- The UAE, Shaker, Maastricht, pp 194-240.

[31] Soon, T. T. (1994) 'A Pragmatic Approach to SME Development in Singapore' Journal of Small Business and Entrepreneurship, Vol 11, No.2, pp. 3845.

[32] SMBA (2015). SME Policy. Seoul:The Small and Medium Business Administration.

http://www.smba.go.kr/eng/polities/smepo licies_01.do?mc=usr0001170

(Accessed December, 2015).

[33] Teng, H. S. S. (2011). Government Policy and Critical Success Factors of Small Business in Singapore. New Castle: Cambridge Scholars Publishing.

[34] Trade and Industry Department (2012). A Report on Support Measures for Small and Medium Enterprises. Hong Kong: Trade and Industry Department. https://www.tid.gov.hk/print/english/about us/publications/smes/smes04.html (Accessed December, 2015).

[35] UNIDO (2001) Development of Clusters and Networks of SMEs, The UNIDO SME Programme, United Nations Industrial Development Programme, Vienna.

[36] Wei-Yen, D. H. (2004) SME Policies and SME Linkage Development in Singapore. Chapter in Wei-Yen, D.H. and Nee. L.W. (Eds.), Entrepreneurship and SMEs in Southeast Asia's Economic Development (pp.175-20). Singapore: Institute of Southeast Asian Studies,

[37] World economic Forum (2015) The Global Competitiveness Report 2015-2016. Genenva: World Economic Forum.

[38] http://reports.weforum.org/globalcompetitiveness-report-2015-

2016/competitiveness-rankings (Accessed August, 2015).

[39] Websites - ASME (2015). Singapore: Association of SMEs. http://www.asme.org.sg/index.php/about_a sme (Accessed September, 2015).

[40] Dubai SME (2015). Dubai: Dubai SME. https://www.google.com/search?q=dubai+ sme \&ie $=$ utf-8\&oe $=$ utf- $8 \quad$ (Accessed August, 2015).

[41] Emirate Businesswomen Councilwww.uaebwc.ae_(Accessed August, 2015).

[42] Enterprise International Singapore (2015). Singapore: Enterprise International Singapore. http://www.iesingapore.gov.sg/ (Accessed September, 2015).

[43] IDA (2015). Singapore: Infocomm Development Authority. 
https://www.ida.gov.sg/Programmes-

Partnership/Small-and-Medium-

Enterprises (Accessed September, 2015).

[44] Khalifa Fund (2015). AbuDhabi: Khalifa Fund, Abu Dhabi. www.khalifafund.ae/. (Accessed August, 2015).

[45] NBR (2015). Abu Dhabi: National Bureau of Statistics.

http://www.uaestatistics.gov.ae/EnglishHo me/ (Accessed July, 2015).

[46] SPRING Singapore (No Date). Singapore: SPRING Singapore.

http://www.spring.gov.sg/Resources/Docu ments/Corp_Marketing_Brochure_Eng.pd (Accessed September, 2015).

[47] SPRING Singapore (2015). Singapore: SPRING Singapore (last updated January 25, 2015).

http://www.spring.gov.sg/NewsEvents/PR/ Pages/More-SMEs-Raised-ProductivityInnovated-and-Upgraded-Capabilities-in2012-20130219. aspx(Accessed September, 2015).

[48] World Bank Data (2015). Washington DC: World Bank.

http://data.worldbank.org/indicator/NY.G DP.MKTP.CD?page = (Accessed July, 2015). 